\title{
The Use of Bauxite as an Arsenic Filter*
}

\author{
${ }^{1}$ S. A. Ndur*, ${ }^{1}$ H. Osei, ${ }^{2}$ C. E. Abbey, ${ }^{1}$ T. Joe-Asare \\ ${ }^{1}$ University of Mines and Technology, Tarkwa, Ghana \\ ${ }^{2}$ Missouri University of Science and Engineering Development, Rolla
}

Ndur, S. A., Abbey, C. E., Osei, H. and Joe-Asare, T. (2019), "The Use of Bauxite as an Arsenic Filter", Ghana Mining Journal, Vol. 19, No. 2, pp. 55-63.

\begin{abstract}
Arsenic (As) has the potential to negatively affect soils and groundwater quality, and cause several public health challenges. It is usually concentrated and released during metal mining of ores that contains arsenic-bearing minerals. Remediation strategies are in place to avoid pollution. In this study, bauxite from Awaso, Ghana, was characterised, and its ability to sequester As was tested under varying conditions of temperature, Eh and $\mathrm{pH}$. The study showed that the best particle size in the range utilised was $80 \%$ passing $2 \mathrm{~mm}$ as it allowed easy percolation, and As removal was about $95 \%$. The reaction is a favourable pseudo-second order reaction that is spontaneous and thermodynamically stable and compares well with the Langmuir Sorption Isotherm. About 80\% sorption was achieved within 20 minutes of contact with low desorption rate of less than $1.8 \%$. The study thus concludes that bauxite is a good filter for arsenic.
\end{abstract}

Keywords: Arsenic, Bauxite, Filter, Sorption, Isotherm

\section{Introduction}

Arsenic (As) is a drinking water toxicant of great public concern because it is a "class A" human carcinogen when ingested, inhaled or assimilated into the skin (Antman, 2001). Arsenic occurs naturally in refractory gold ores (Kesse, 1985). Arsenic concentrations in mine waste effluents are of major concern to mining companies that process arsenic-bearing minerals because during mineral beneficiation it is released into waste effluent dams and this can get into the environment either through seepage or dam failures. In Ghana, some gold mining companies work on arsenic-containing refractory gold ores. When minerals such as arsenopyrite are exposed, oxidation occurs causing acid mine drainage and subsequently mobilisation of arsenic in the environment.

For companies using the bio-oxidation process, solubilized arsenic may be neutralized using hydrated lime to convert arsenic to relatively stable ferric and calcium arsenates; however, the efficiency is low, especially at low arsenic concentrations. In addition, the neutralization reactions are effective with $\mathrm{As}^{5+}$ (Arsenate) than $\mathrm{As}^{3+}$ (Arsenite) (Aronson, 1994). Though the neutralized sludge is usually stored in tailings impoundments, seepage and dam failures can cause the solubilised arsenic to leak into the local environment.

Severe arsenic poisoning can result from the ingestion of minute quantities and chronic effects can be seen with accumulation of arsenic compounds in the body even with low intake (Antman, 2001). Arsenic has carcinogenic properties (Chen et al., 1999) and has been associated with cancers of the skin, lung and bladder. The current WHO recommended guideline value for arsenic in drinking water is $10 \mu \mathrm{gL}^{-1}$

whereas many developing countries are still having a value of $50 \mathrm{\mu gl}^{-1}$ (Chen et al., 1999; Antman, 2001; Anon., 2008).

Existing technologies to remove arsenic from water include neutralization using hydrated lime to convert arsenic to relatively stable ferric and calcium arsenates. The use of biomass (Williams, 2006), mineral oxides, polymer resins and activated carbon have been reported (Benjamin et al, 1996; Dambies et al., 2002). Remediation of arsenic using laterite iron concretions (LIC) (Partey et al., 2008) and nanotechnology (Biney, 2010). Oxides of iron, aluminium, titanium and manganese have been used to remediate drinking water arsenic in Bangladesh and India (Aronson, 1994). Some researchers have also used bauxite (Ndur et al., 2002; Ayoob, 2007).

Bauxite, a naturally occurring mineral, is the main ore for aluminium. Bauxite has major components such as aluminium oxide $\left(\mathrm{Al}_{2} \mathrm{O}_{3}\right)$, iron oxide $\left(\mathrm{Fe}_{2} \mathrm{O}_{3}\right)$ and rutile $\left(\mathrm{TiO}_{2}\right)(\mathrm{Kesse}, 1985)$. Large deposits of bauxite are in Ghana at Awaso, Nyinahin and Kibi and could serve as a good sorbent for arsenic because of its composition. The aim of this study is to investigate the use of bauxite from Awaso, Ghana, in the sorption of arsenic from water.

\section{Resources and Methods Used}

Three types of bauxite were analysed to determine their sorption capabilities. These are red (iron rich) bauxite, white (alumina rich) and orange (mixture of iron and alumina) bauxite were taken from three different stockpiles at the Ghana Bauxite Company in Awaso for analysis. Test works included particle size analysis, mineralogical analysis using XRF and 
Neutron Activation Analysis (NAA). Sorption and desorption tests were also conducted. The sorption tests were done to establish if bauxite was capable of adsorbing arsenic and consequently to quantify and investigate the sorption kinetics.

About $2.00 \mathrm{~kg}$ each of three types of bauxite samples was used for the investigation. The bauxite samples were air-dried and representatively split into various fractions and quantities necessary for the various analysis required. Three arsenic-containing effluent waters from ponds at AngloGold Ashanti Obuasi Mine were used to assess the efficiency of arsenic remediation using bauxite. These are the Holding Pond (HP), Tailings Pond (TP) and Nyam stream.

\subsection{Particle Size Distribution (PSD) Analysis}

PSD analysis was conducted on $2 \mathrm{~kg}$ representative samples of each bauxite type using screens built according to the Tyler series (Wills, 1985) with the topmost screen aperture size being $3.0 \mathrm{~mm}$. A particle size range of $-0.212 \mathrm{~mm}+1.118 \mathrm{~mm}$ was used for the sorption tests. Below this size range the particles were too fine and had the potential to pose percolation problems.

\subsection{Mineralogical Analysis}

To establish the mineral composition and find out the components responsible for arsenic sorption; analyses X-ray Fluorescence (XRF), Neutron Activation Analysis (NAA) and Fourier Transform Infra-red Spectrometry (FTIR) were conducted on the samples For the NAA analysis, Controls and Standards, IAEA-Soil 7, and IAEA-Soil 3, were added to the test samples. FTIR analysis was necessitated by the need to establish the functional groups that interact with arsenic during and after sorption. These analyses were conducted on the bauxite samples before sorption tests and on the residue after sorption to allow comparison, and also provide vital information as to the state and nature of As in the matrices of the bauxite molecules after sorption.

\subsection{Sorption Tests}

Column sorption tests were carried out to establish the possibility of using bauxite to sorb arsenic from solution. The variables investigated included particle size, contact time, solution concentration, flow rate and bauxite type. For each test, $500 \mathrm{~g}$ of bauxite sample crushed and sized to $2 \mathrm{~mm}$ was introduced into an air tight $6 \mathrm{~cm}$ diameter glass econo-column to a height of $20 \mathrm{~cm}$. The column was initially saturated with distilled water to dispel air trapped in the column. Liquid flow through the column was regulated by an NSF microprocessor dosing pump model A971-35151 fitted to the top of the column via plastic tubes. The same set-up as shown in Fig 1 was used to run two tests: Sorption tests using BIOX effluent with high (1400 ppm) arsenic concentration.

These tests were done for an initial 2 hours period to establish sorption possibility and then 72 hours to study the kinetics. Samples were taken at 20 minuteintervals. Parameters analyzed included $\mathrm{pH}$, Eh, temperature, and arsenic concentration. The column, bauxite and solution used for the sorption tests were found to have the parameters shown in Table 1.

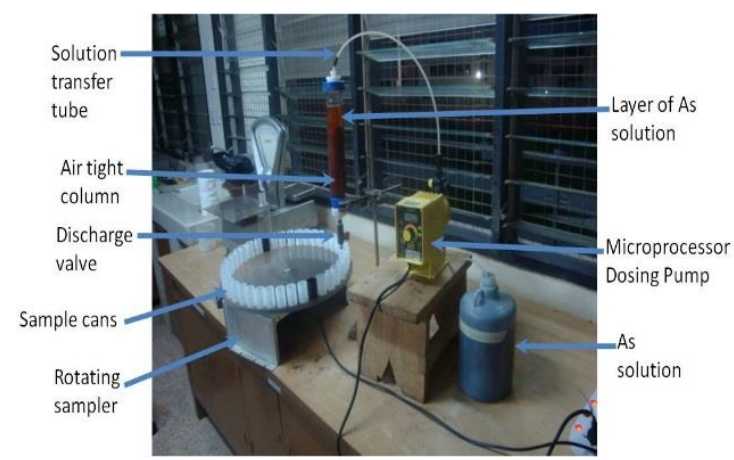

Fig. 1 Experimental Set Up for Sorption and Desorption Test Work

Table 1: Measured Experimental Conditions of the Column, Bauxite and Solution

\begin{tabular}{|l|l|l|}
\hline Parameters & $\begin{array}{l}\text { Measured } \\
\text { values }\end{array}$ & Units \\
\hline $\begin{array}{l}\text { Column inner diameter } \\
\text { (d) }\end{array}$ & 6 & $\mathrm{~cm}$ \\
\hline $\begin{array}{l}\text { Volumetric discharge } \\
\text { (Q) }\end{array}$ & 4 & $\mathrm{ml} / \mathrm{min}$ \\
\hline Length (L) & 20 & $\mathrm{~cm}$ \\
\hline $\begin{array}{l}\text { Surface Area of column } \\
\text { (A) }\end{array}$ & 28.28571 & $\mathrm{~cm}^{2}$ \\
\hline Volume Flushed & 17300 & $\mathrm{~L}$ \\
\hline Mass of bauxite & 500 & $\mathrm{~g}$ \\
\hline Initial Conc., TP & 13.263 & $\mathrm{ppm}$ \\
\hline Initial Conc., HP & 9.29 & $\mathrm{ppm}$ \\
\hline Initial Conc., Nyam & 0.447 & $\mathrm{ppm}$ \\
\hline Particle Size (P80) & 2 & $\mathrm{~mm}$ \\
\hline
\end{tabular}

For each type of experiment, the total mass of arsenic flushed, mass output, total mass sorbed, bed performance and sorption per unit bed length were calculated.

\subsection{Column Desorption Tests}

After sorption, it was necessary to investigate the state of arsenic on the bauxite and whether the sorbed arsenic may be stripped easily for arsenic to be released into the environment. Stripping or desorption tests with de-ionized water and rain water were conducted. Solution samples were drawn periodically and analyzed for As. FTIR analysis was compared before and after the sorption test. 


\section{Results and Discussion}

\subsection{Bauxite Characterisation}

PSD analysis shows that red bauxite had the coarsest particle size distribution ( $80 \%$ passing $2.20 \mathrm{~mm}$ ) followed by the yellow bauxite (80\% passing 2.13 $\mathrm{mm})$ and finally white bauxite (80\% passing 2.01 $\mathrm{mm})$.

XRF analysis of the red bauxite, reveals the predominance of compounds such as $\mathrm{Al}_{2} \mathrm{O}_{3}, \mathrm{Fe}_{2} \mathrm{O}_{3}$, $\mathrm{TiO}_{2}$ and $\mathrm{SiO}_{2}$ along with other trace metal oxides such as $\mathrm{P}_{2} \mathrm{O}_{5}, \mathrm{Na}_{2} \mathrm{O}, \mathrm{CaO}$ and $\mathrm{MnO}$. These metal oxides are known to absorb arsenic from solution (Bhatar et al, 2006; Gile et al, 2011).

The winplot (Fig. 2) of the NAA of the initial bauxite and As-received bauxite shows a significant reduction in the concentration of Arsenic in the HP, TP and Nyam solutions. The sorption of Arsenic by the bauxite can be attributed to the presence of oxides of $\mathrm{Al}, \mathrm{Fe}$ and $\mathrm{Mn}$, and other trace metal oxides These results were confirmed by the FTIR analyses as shown in figure 3 . From figure 3, OR represent the FTIR plot for the treated bauxite whereas Nyam, HP and TP represent the FTIR plot for the As-received bauxite (Treated bauxite contacted with samples from the Nyam stream, Hold pond and the Tailing pond).

There were other elements like titanium, sodium, magnesium, potassium, phosphate, sulphur, manganese and calcium. The most significant changes were in the Loss-on-Ignition (LOI) which was lower for the initial sample compared to the Asreceived samples. $\mathrm{SiO}_{2}$ in the As-received bauxite was lower compared to the initial bauxite. The major metal oxides present were iron and aluminium. Calcium oxide had similar percentages for all samples except for the initial sample which contained lower calcium oxide. Titanium oxide also had same values but for the initial sample which had higher counts.

Table 2 shows the average As values of the bauxite sample before and after the sorption test and their respective percent rise after sorption. Arsenic concentrations increased by over $200 \%$ in all cases with the highest being HP and the lowest being Nyam. This buttresses the assertion that As was sorbed onto the bauxite.

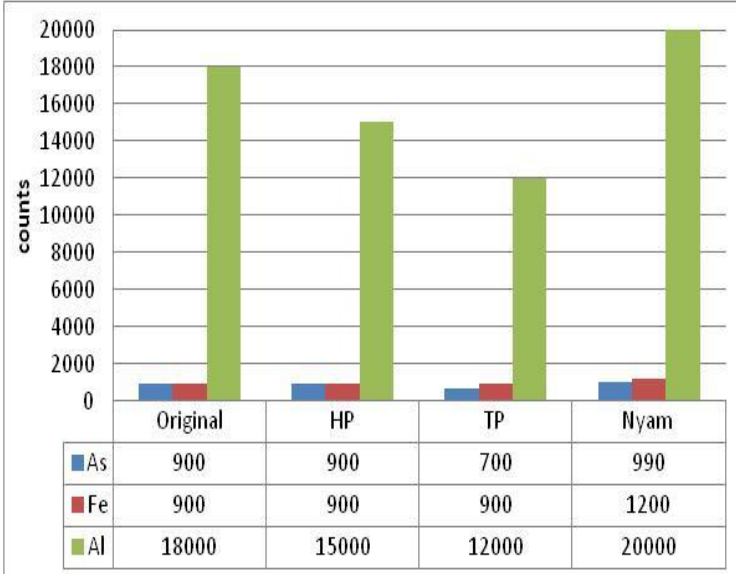

Fig. 2 NAA Results of HP, TP and Nyam with their Respective Counts

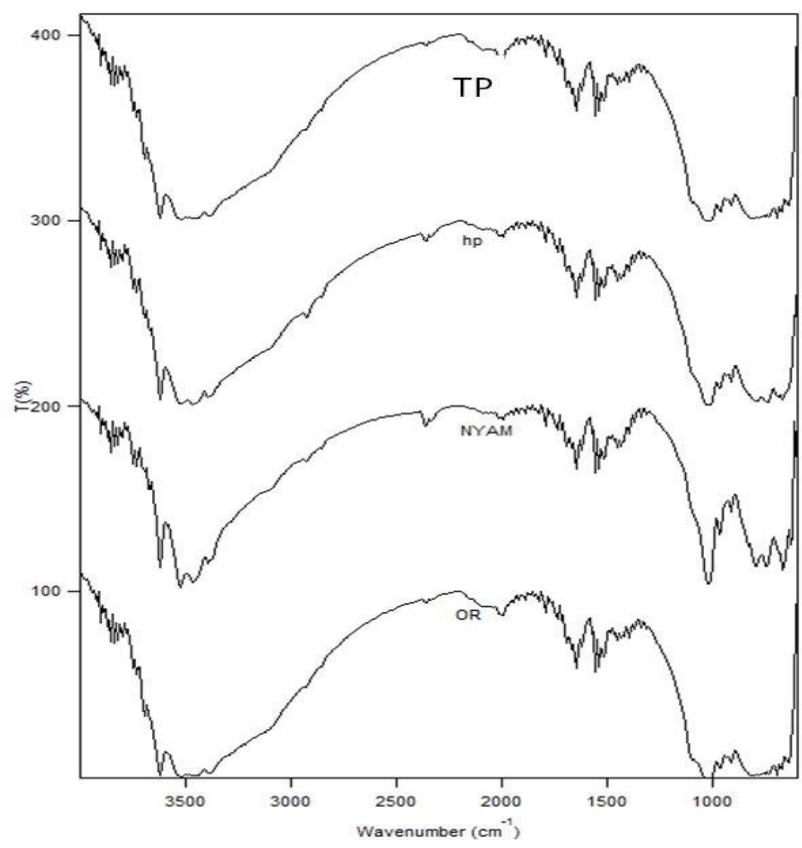

Fig. 3 FTIR Plot of Treated and As-Received Bauxite

Table 2 Average As Values from XRF for Initial Sample, TP, HP and Nyam Residues

\begin{tabular}{|l|l|l|}
\hline Sample & $\begin{array}{l}\text { As } \\
\text { Concentration } \\
(\mathbf{p p m})\end{array}$ & $\begin{array}{l}\text { Percentage } \\
\text { Increase } \\
(\%)\end{array}$ \\
\hline Initial & 44.38 & $\begin{array}{l}\text { Average } \\
\text { Initial }\end{array}$ \\
\hline $\begin{array}{l}\text { After contact } \\
\text { with TP }\end{array}$ & 102.9 & 231.861 \\
\hline $\begin{array}{l}\text { After contact } \\
\text { with HP }\end{array}$ & 112.5 & 253.493 \\
\hline $\begin{array}{l}\text { After contact } \\
\text { with Nyam }\end{array}$ & 95.8 & 215.863 \\
\hline
\end{tabular}

The FTIR was to compare the functional groups on the sample before and after sorption. Attention was 
given to the region $4000-3000 \mathrm{~cm}^{-1}$ of spectra since most changes are expected to be seen in this region for the sorption of both arsenite and arsenate (Vithanage et al., 2006). The spectrum had no characteristic peaks for terminal $\mathrm{OH}$ groups.

When compared to the original spectrum of bauxite before sorption, a marked difference of the peak intensities was observed, particularly in the spectral regions 4000-3000, 2500-500 $\mathrm{cm}^{-1}$. Peaks observed between 1250 and $650 \mathrm{~cm}^{-1}$ are ascribed to metal oxide bonds such as $>\mathrm{Al}-\mathrm{O}$ and $>\mathrm{Fe}-\mathrm{O}$ vibrations. After sorption the bauxite spectrum showed a characteristic peak in the region $4000-3000 \mathrm{~cm}^{-1}$ (Fig. 3). Myneni et al., (1998) presented an arsenic reaction with freshly prepared hydrous iron oxide, which produced peaks at 700,802 , and 875 , and for goethite $719,730,810,838$, and $938 \mathrm{~cm}^{-1}$. These are similar to Fig. 4. The assignable peaks are $\mathrm{Al}-\mathrm{O}-\mathrm{H}$ vibration and it was intense in the samples after adsoption, which indicates $\mathrm{Al}-\mathrm{O}-\mathrm{As}$ bond formation. Peaks recorded in the region 1200-900 $\mathrm{cm}^{-1}$ by Goldberg and Johnston (2001) for Fe oxides appeared in before and after samples which can be assigned to surface complex formation and arsenate sorption on goethite. The IR spectra looked similar to that in Castaldi et al., (2010) when the red sample was used.

In studies by Ayoob et al. (2006) and Bhakat et al. (2006), X-Ray Diffraction was used to analyse the samples after contact with arsenic. After sorption the authors observed that the main oxides were arsenic oxide, aluminium arsenate, iron arsenate, iron oxide arsenate, calcium arsenate and calcium arsenic oxide. This shows the state of As and the interactions between bauxite and As. It was inferred that same or similar bonds would be formed in the current study.

\subsection{Sorption Tests and Kinetics}

Due to the soft and fine nature of white bauxite, there were percolation problems when the experiment was attempted several times. The column got clogged and had to be dismounted. From the results, red bauxite had better sorption capacity. The yellow bauxite performed satisfactorily but got clogged after 80 minute. Comparing the performance after 80 minutes red bauxite was better in terms of percolation. Orange bauxite reduced arsenic concentration from $1400 \mathrm{mg} / \mathrm{L}$ to 0.684 $\mathrm{mg} / \mathrm{L}$. Both ore types were able to reduce the arsenic concentration from $1400 \mathrm{mg} / \mathrm{L}$ to below $70 \mathrm{mg} / \mathrm{l}$ in the initial 20 minutes. Red bauxite was chosen for carrying out the rest of the arsenic sorption test due to percolation problems of the orange; though the yellow performed better at least before it got clogged.
The optimum red bauxite grain size was $2 \mathrm{~mm}$. A close look at Figure 4 shows that the finer particle sizes present better sorption effects obviously due to its larger surface area available for solution contact. The $2 \mathrm{~mm}$ size fraction was chosen in conducting the rest of the test though the $1.18 \mathrm{~mm}$ showed better arsenic remediation capabilities because the finer grain sizes also posed percolation problems.

\subsubsection{Break Through Curves}

The results of the break through curves are shown in Fig. 5. Breakthrough curves help to appreciate the efficiency and rate of effluent velocity through the column. Two hour sorption tests were carried out on the solution samples taken from TP, HP and Nyam with their known initial arsenic concentrations. $\mathrm{C} / \mathrm{C}_{0}$ is the relative breakthrough concentration and it shows arsenic removal with time by bauxite from each of the effluent solutions.

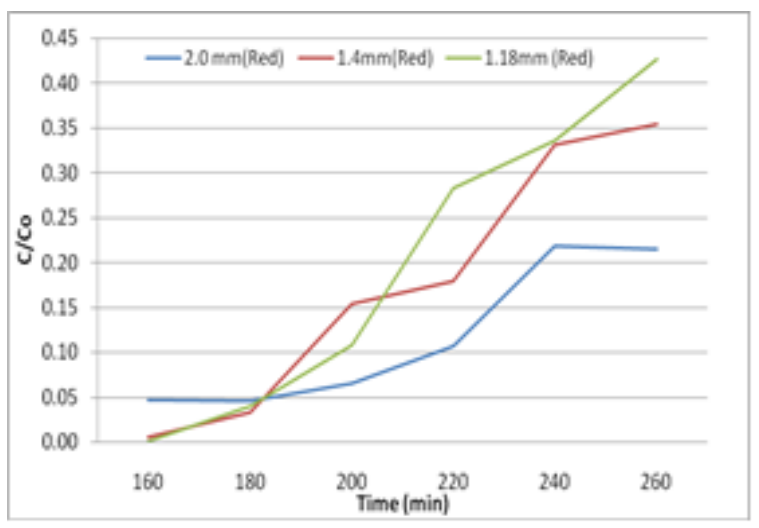

Fig. 4 Effect of Particle Size on Sorption of Arsenic by Red Bauxite

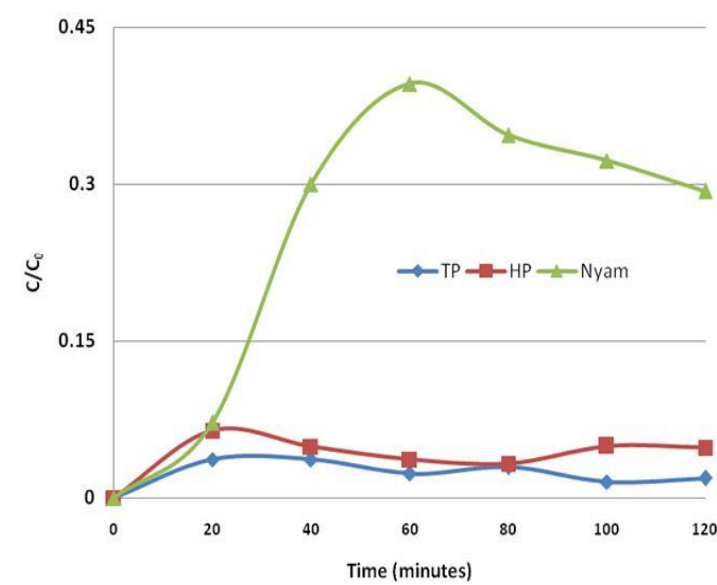

Fig. 5 The initial 2-hour Sorption Tests of Relative Breakthrough Concentration of Arsenic with Time for HP, TP and Nyam Water Types

Breakthrough was gradual with steady removal of arsenic from all solutions (HP, TP and Nyam) over 120 minutes, the removal of arsenic from samples 
from the tailing pond (TP) and holding pump was relatively higher and indicated about $85 \%$ reduction in the initial concentration from the raw values (Fig 5). Arsenic removal from the Nyam water was equally high with maximum breakthrough concentration less than 0.5 (peak maximum $\mathrm{C} / \mathrm{C}_{0}=0.38$ ) even though when compared with the samples from TP and HP arsenic sorption onto the bauxite was low perhaps due to the low initial concentration of Nyam.

In carrying out this test, sorption was again conducted with known concentration in $\mathrm{mg} / \mathrm{l}$ of effluent solution, Eh, $\mathrm{pH}$ and temperature over a 72 $\mathrm{hr}$ period to establish the point of bauxite's full saturation. Fig. 6 shows the graph of the relative breakthrough concentration against time

From Fig. 6, it was observed that, for all three samples, concentration of the initial arsenic input reduced by more than $80 \%$. For samples from TP with initial concentration $13.263 \mathrm{ppm}$ there was complete removal or sorption of arsenic onto the surfaces of the bauxite making it a good treatment method. For HP treatment, it was observed that arsenic concentration in the effluent started to rise after 50 hours. This effect is attributable to saturation of the sorption sites on the bauxite. The experiment with the sample from Nyam showed a constant removal of arsenic over the duration of the experiment. From these observations, it is clear that, for the samples taken from the three different sites, arsenic removal from the Tailings Pond (TP) was the highest; arsenic removal from Holding Pond (HP) with initial concentration of 9.29 ppm was equally good up till 50 hours.

As observed from the interpretation of breakthrough curves, arsenic removal by bauxite in samples from the Tailing Pond (TP) was higher than the other two treatment effluents, this was the case notwithstanding the initial As concentration in TP was higher. From these observations, it may be likely that; when arsenic concentration is high, removal by bauxite is also higher as seen in Figure 6.

Arsenic sorption onto bauxite is very efficient since the initial concentration of As used to flush the column was 13.263 (TP). The average concentration of effluent was $0.334 \mathrm{mg} / \mathrm{l}$. This means that $97.5 \%$ reduction after sorption. A double stage purification approach can be used to remediate As and reduce it to the WHO standard 0.01 ppm (Anon., 2008).

\subsubsection{The Effect of Temperature, Eh and $\mathrm{pH}$}

Analysis of variance (ANOVA) was used to compare mean values of measured physical parameters, this was to assess whether each effluent;
TP, HP and Nyam had significant effects on the physical properties of the effluent and whether arsenic removal was dependent on any of the parameters. A high erratic temperature profile was observed for the samples from the Nyam (Figure 7); starting from $27.35^{\circ} \mathrm{C}$ and reducing to about $25.35^{\circ} \mathrm{C}$ by the first 20 minutes, until the final temperature of about $25.8^{\circ} \mathrm{C}$ by the end of the run. Similar trends were observed in the breakthrough curves for the two hour run. The $20^{\text {th }}$, and $60^{\text {th }}$ minutes trends were in consonance in both temperature and breakthrough curves.

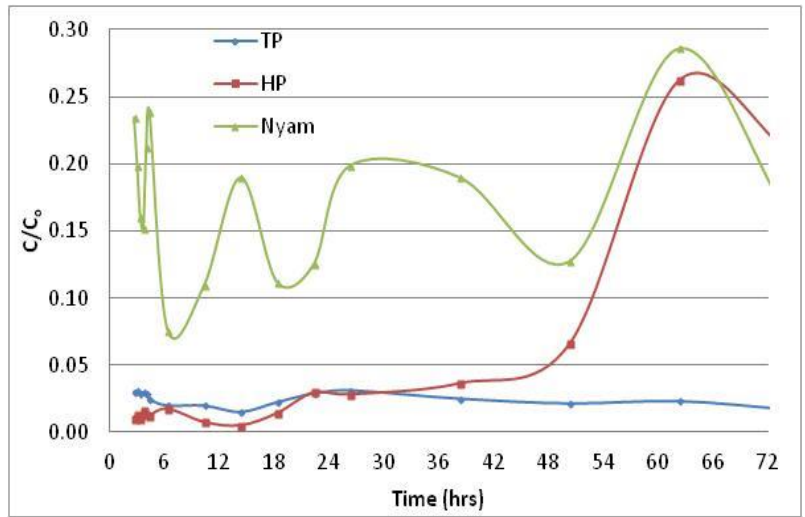

Fig. 6 The Relative Breakthrough Concentration of As with Time for HP, TP and Nyam

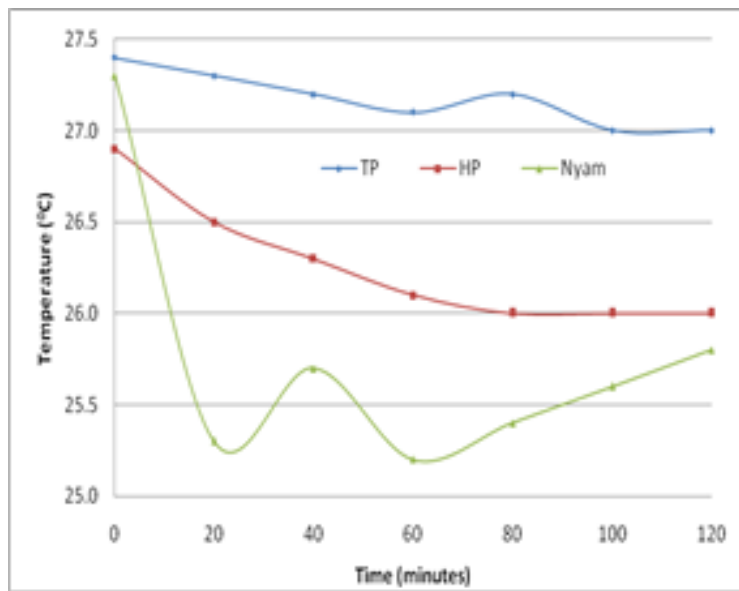

Fig. 7 Time against Temperature Graph for Initial 2hours for HP, TP and Nyam

The temperature profile for the 72 hour run was erratic but interestingly below the measured atmospheric temperature $\left(29.3^{\circ} \mathrm{C}\right)$ while the set up was running with the range spanning over $4^{\circ} \mathrm{C}$. Ayoob et al. (2007) and Bhakat et al. (2006) also did similar work with Modified Calcined Bauxite (MCB) and realized that there were appreciable temperature effects in As removal.

As Eh decreased, $\mathrm{pH}$ increased as shown in Figure 8, with comprehensive decrease in temperature. HP and Nyam both had Eh/pH changes around the initial 20 minutes but TP was smoother till about the $60^{\text {th }}$ minute. This shows that there is a relation 
between temperature, Eh and $\mathrm{pH}$ measured during the sorption. Nyam showed the optimum sorption thus indicating higher remediation of the effluent arsenic, thus showing the lowest temperature, lowest Eh and highest $\mathrm{pH}$.

Analysis of Variance (ANOVA) was used to compare mean values of measured physical properties (Temperature, Eh and $\mathrm{pH}$ ). This was to compare and assess the effect of bauxite on the measured properties after samples were flushed through the columns. The means were compared and tested at a significant value of $p<0.05$ indicating that for probability i.e. $p$-values $<0.05$ average values of measured physical properties were considered to be significantly different from each other, such a result will indicate that there is $95 \%$ similarities among the values. The Eh results indicated that the average measured values for the effluents of the three different samples were statistically not different from each other with $\mathrm{p}$-values $>0.05$ for all pairs (TP and HP: $p=0.33$; HP and Nyam: $p=0.13$ and Nyam and TP: $p=0.07)$. Superimposing the actual Eh and $\mathrm{pH}$ graphs shows a good mirror effect as seen in Fig. 8 .

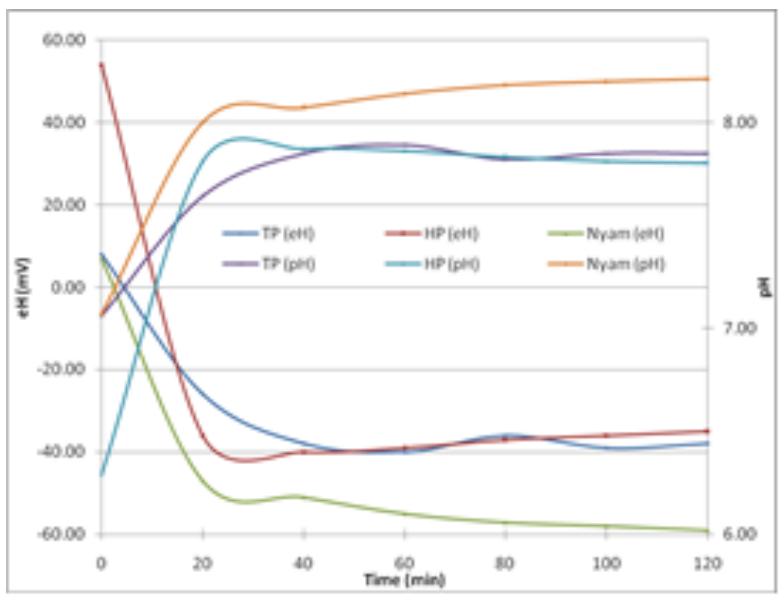

Fig. 8 Time against $\mathrm{Eh}$ and $\mathrm{pH}$ for 120 Minitues Graph

ANOVA was also done on the average $\mathrm{pH}$ values to establish the statistical significance and whether they were statistically different. ANOVA revealed that average $\mathrm{pH}$ values were similar for the samples (TP and HP: $p=0.61$; HP and Nyam: $p=0.08$; Nyam and TP $p=0.11$ ). The effect of $\mathrm{pH}$ is very important in speciation of As and its sorption capabilities (Ayoob et al., 2007; Bhakat et al., 2006). $\mathrm{pH}$ influences speciation and therefore the operation $\mathrm{pH}$ determines the ion species of As being sorbed onto the sorbent. To achieve good sorption of As (III) requires very low $\mathrm{pH}$ (Singh and Pant, 2004). The best range is between 2 and 4 (Lin and $\mathrm{Wu}, 2001)$ though it works very well up to a $\mathrm{pH}$ of 7. The removal of As from solution is very dependent on $\mathrm{pH}$ during sorption; the surface charge of the sorbent, degree of ionization and As speciation is also very relevant (Ayoob et al., 2007).

\subsection{Sorption Isotherms}

Test work on Modified Calcined Bauxite (MCB) by Ayoob et al. (2007) tested four kinetic models and established that the mechanism was mainly by chemisorption/chemical bonding which involved valence forces through sharing and exchange of electrons between sorbent and sorbate and this may be responsible for sorption. This fitted the pseudo second order model most with regression curve and $\mathrm{R}^{2}$ value greater than 0.99 .

Equilibrium studies were further conducted and the Langmuir and Freundlich models were tested and compared with the sorption models obtained. Figures 9 and 10 show the Freundlich and Langmuir Isotherms for the equilibrium concentrations obtained.

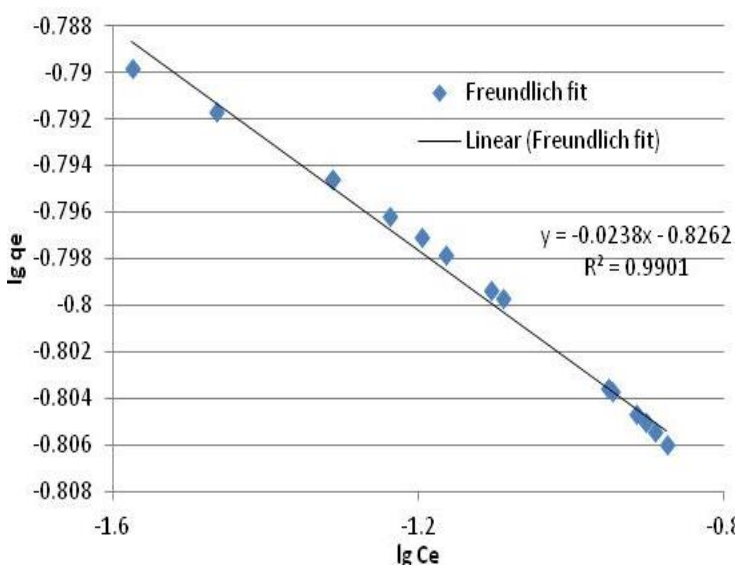

Fig. 9 Freundlich Sorption Isotherm for TP

The line of best fits was obtained and the regression coefficient $\mathrm{R}^{2}$ was calculated to determine the isotherm that fitted best. The equations were then compared with the isotherm equation to help calculate the isotherm constants for both Freundlich and Langmuir. Subsequently, the maximum sorption capacity $\left(\mathrm{q}_{\max }\right)$, the dimensionless separation factor (r) (Biney, 2010) and the Gibbs free energy $\Delta \mathrm{G}^{0}$ were calculated.

Many isotherms exist (Altundogen et al., 2000). The most commonly used is Langmuir and Freundlich. A lot of research in this area shows that the sorption of As onto iron oxides and other oxides mostly fit well to the Langmuir isotherm (Biney, 2010; Zhang et al., 2003; Singh et al., 1988; Gupta and Chen, 1978; Harper and Kingham, 1992; Partey et al., 2008). From the isotherms in this study; the $\mathrm{R}^{2}$ values shows a strong agreement to the Langmuir isotherm. 
Furthermore, the dimensionless constant separation factor (r) (Altundogan et al., 2000; Biney, 2010; McKay et al., 1985) was calculated to be 0.036332 and 0.001263 . These are between 0 and 1 and therefore show that sorption of As onto bauxite is favourable at all the initial concentrations used. The standard Gibbs free energy $\left(\Delta G^{0}\right)$ was calculated using Equation 1

$$
\ln (1 / \mathrm{b})=\Delta \mathrm{G}^{0} / \mathrm{RT}
$$

and found to be $-10.2523 \mathrm{~kJ} / \mathrm{mol}$. In Equation 1, b is the Langmuir's constant, $\mathrm{R}$ is the ideal gas constant $(8.314 \mathrm{~J} / \mathrm{K} \mathrm{mol})$ and $\mathrm{T}$ is the temperature in Kelvin $(\mathrm{T}=23+273 \mathrm{~K}=296 \mathrm{~K})$. This indicates that the sorption process is spontaneous and thermodynamically stable. The maximum sorption capacity $\left(\mathrm{q}_{\max }\right)$ was found to be 2.2774 . This is comparable to $\mathrm{q}_{\max }$ values obtained by Ayoob et al. (2007) and Biney (2010) as shown in Table 3

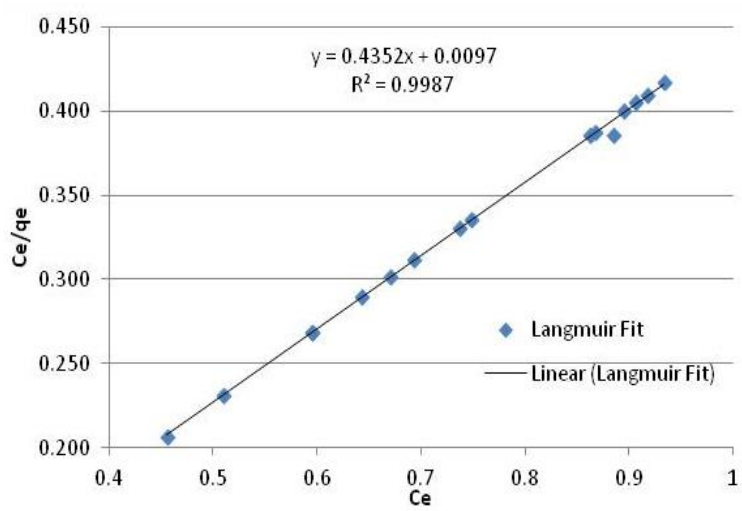

Fig. 10 Langmuir Sorption Isotherm for TP

Table 3 Comparison of As Adsorption Potential of Bauxite with other Materials (Modified after Ayoob et al., 2007)

\begin{tabular}{|c|c|c|}
\hline $\begin{array}{c}\text { Name of } \\
\text { Adsorbent }\end{array}$ & $\underset{(\mathbf{m g} / \mathbf{g})}{\mathbf{q m a x}}$ & References \\
\hline $\begin{array}{l}\text { Ferruginous } \\
\text { manganese ore }\end{array}$ & 0.680 & $\begin{array}{l}\text { Chakravarty et al., } \\
2002\end{array}$ \\
\hline $\begin{array}{l}\text { Iron oxide } \\
\text { coated sand }\end{array}$ & 0.029 & Gupta et al., 2005 \\
\hline $\begin{array}{l}\text { Activated } \\
\text { alumina }\end{array}$ & 0.1803 & $\begin{array}{l}\text { Singh and Pant, } \\
2004\end{array}$ \\
\hline $\begin{array}{l}\text { Iron oxide } \\
\text { impregnated } \\
\text { activated } \\
\text { alumina }\end{array}$ & 0.734 & $\begin{array}{l}\text { Kuriakos et al., } \\
2004\end{array}$ \\
\hline Red mud & 0.66 & $\begin{array}{l}\text { Altundogan, et al., } \\
2000\end{array}$ \\
\hline $\begin{array}{l}\text { Activated red } \\
\text { mud }\end{array}$ & 0.87 & $\begin{array}{l}\text { Altundogan, et al., } \\
2002\end{array}$ \\
\hline $\begin{array}{l}\text { Modified } \\
\text { calcined bauxite }\end{array}$ & 1.362 & Ayoob et al., 2007 \\
\hline $\begin{array}{l}\text { Magnetite nano- } \\
\text { particles }\end{array}$ & 2.3596 & Biney, 2010 \\
\hline Bauxite & 2.2774 & Current work \\
\hline
\end{tabular}

\subsection{Desorption Test}

The safety of the environment is very important. Due to this, it is necessary to establish if the sorbed As would be stable on the bauxite so that if it is used there is no risk of desorption or releasing the As back into the environment. This could cause ground water pollution and make As remediation efforts futile. De-ionized water was used to flush a bauxite sample that had already been flushed with As solution. The highest desorption value recorded was $0.227 \mathrm{mg} / \mathrm{l}$, the lowest value was $0.004 \mathrm{mg} / \mathrm{l}$ with an average value of $0.051 \mathrm{mg} / \mathrm{l} \mathrm{As}$ concentration. Initial As concentration before sorption was $13.263 \mathrm{mg} / \mathrm{l}$ (TP). The average As concentration of the effluent during sorption was $0.334 \mathrm{mg} / \mathrm{l}$; meaning there was a retention of $12.929 \mathrm{mg} / \mathrm{l}$. This is therefore below 1.8 $\%$ desorption even if the maximum As value $(0.227$ $\mathrm{mg} / \mathrm{l}$ ) for desorption was considered. This means that sorbed As would be stable in bauxite if used for As remediation.

\section{Conclusions and Recommendations}

The study has established the As sorption capacity of bauxite mined at Awaso, Ghana. Three bauxite types; high alumina (white), high iron (red) and mix of red and white (orange) were used. Particle size distribution conducted proved that $80 \%$ of all three bauxite types could pass $2.11 \mathrm{~mm}$. Red bauxite had the coarsest particle size distribution $(80 \%$ passing $2.20 \mathrm{~mm}$ ) followed by the orange bauxite $(80 \%$ passing $2.13 \mathrm{~mm}$ ) and finally white bauxite $(80 \%$ passing $2.01 \mathrm{~mm}$ ). White and orange bauxite did not perform well because their particles were too fine and percolation was inefficient. The best particle size performance was by $80 \%$ passing $2 \mathrm{~mm}$.

The highest efficiency (99.95\%) was measured with red bauxite but in the first 20 minutes As removal was about $95 \%$. Effluent breakthrough was gradual and steady. The 72 hour tests showed more than 80 $\%$ As removal. $\mathrm{pH}$ ranges between 2 and 4 are the most effective, but it works well up to $\mathrm{pH}$ 7. Studies show that the sorption of As onto bauxite is a pseudo-second order reaction and hence sorption is mainly by chemisorption or chemical bonding. The Langmuir isotherm best fits the process and is favourable for the entire initial As concentrations tested since the dimensionless constant separation factor (r) was between 0 and 1 . Gibbs free energy calculated for the reaction was negative and therefore the reaction would be spontaneous and thermodynamically stable with a very high sorption capacity of 2.2774 .

The desorption analysis performed showed desorption of about $1.8 \%$. This is very low and good as this would make it very safe for practical applications. XRF analysis shows that As 
concentrations increased by more than $100 \%$ after sorption.

Bauxite has performed efficiently and effectively as a good sorbent for remediating As. It can be effectively developed as a simple, available and cheap household filter for As. In furtherance, refractory ore treatment plants can use bauxite to line their tailing dams and use it for other applications to reduce drastically the As concentrations before releasing treated water into the immediate environment. A stock pile of bauxite can be made available by the plants to use as emergency As remediation techniques during dam spillages since the sorption process is very fast.

\section{References}

Altundogan, H.S., Altundogan, S., Tumen, F., Bildik, M. (2000), "Arsenic Removal from Aqueous Solutions by Sorption on Red Mud", Waste Manage, pp.761-767.

Anon., (2001), "Environmental Health Criteria 224: Arsenic and Arsenic Compound", World Health Organisation, Geneva, pp. 1-108

Antman, K. H. (2001), "Introduction: The History of Arsenic Trioxide in Cancer Therapy" Oncologist, Vol. 6 (Suppl. 2), pp. 1-2.

Aronson, S. M. (1994), "Arsenic and Old Myths", R.I.Med., 77(7), pp.233-4.

Ayoob, S., A.K. Gupta, and Bhakat, P.B. (2007), "Analysis of Breakthrough Developments and Modelling of Fixed Bed Sorption System for As (V) Removal from Water by Modified Calcined Bauxite (Mcb)", Sep. Purif. Technol., pp. 430438.

Ayoob, S., Gupta, A. K, and Bhakat, P.B. (2007), "Performance Evaluation of Modified Calcined Bauxite in the Sportive Removal of Arsenic (III) from Aqueous Environment", Colloids and Surfaces A: Physicochemical. Eng. Aspects, 293, pp. 247-254

Benjamin, M. M., Sletten, R.S., Bailey, R.P., Bennett, T. (1996), "Sorption and Filtration of Metals using Iron-Oxide-Coated Sand", Water Res., 30 (11), pp. 2609-2620.

Bhakat, P.B., Gupta, A.K. Ayoob S. and Kundu, S. (2006), "Investigations on Arsenic (V) Removal by Modified Calcined Bauxite", Colloids Surfaces A: Physicochem. Eng. Aspects, pp. 237245.

Bhattacharya, P., Claesson, M., Bundschuh, J., Sracek, O., Fagerberg, J., Jacks, G., Martin, R.A., del Storniolo, A.R., and Thir, J.M. (2006), "Distribution and Mobility of Arsenic in the R'Io Dulce Alluvial Aquifers in Santiago Del Estero Province, Argentina", Sci. Total Environ., 358 (13) pp. 97-120.

Biney, B., (2010), "Arsenic mineralogy, Geochemistry and Mitigation Using
Nanotechnology-A Case Study," Master of Phylosophy Thesis, University of Mines and Technology, (UMaT), Tarkwa. pp.106.

Castaldia, P., Silvetti, M., Enzob, S., and Melisa, P. (2010), "Study of Sorption Processes and FT-IR Analysis of Arsenate Sorbed onto Red Muds (A Bauxite Ore Processing Waste)" Journal of Hazardous Materials, 175, pp. 172-178

Chakravarty, S., Dureja, V., Bhattacharyya, S., Maity, S., and Bhattacharjee, S. (2002), "Removal of Arsenic from Ground Water Using Low Cost Ferruginous Manganese Ore", Water Res., Vol. 36, No. 3, pp. 36 - 625

Chen, H. W., Frey, M. M., Clifford, D., McNeill, L. S. and Edward, M. (1999), "Arsenic Treatment Considerations"., Water Works Assoc., pp.7485.

Dambies, L., Vincent, T., and Guibal, E. (2002), "Treatment of Arsenic-Containing Solutions using Chitosan Derivatives: Uptake Mechanism and Sorption Performance", Water Res., Vol. 36, pp. 3699-3710.

Goldberg, S., and Johnston, C. T. (2001), "Mechanisms of Arsenic Sorption on Amorphous Oxides Evaluated using Macroscopic Measurements, Vibrational Spectroscopy and Surface Complexation Modelling" J. Colloid Interface Sci., 234, pp. 204-216.

Giles, D.E., Mohapatra, M., Issa, T.B., Anand, S. and Singh, P., (2011), "Iron and aluminium based adsorption strategies for removing arsenic from water". Journal of environmental Management, Vol. 92, No. 12, pp.3011-3022.

Gupta, S. K, and Chen, J. (1978), "Arsenic Removal by Sorption”, Water Pollut. Control Fed., 50 (3), pp.493-506

Harper, T. R., and Kingham, N. W. (1992), "Removal of Arsenic from Wastewater using Chemical Precipitation Methods" Water Environ. Resources., Vol. 64, pp. 200-203.

Kesse, G. O. (1985), "The Mineral and Rock Resources of Ghana" A. A. Balkema, Rotterdam, Holland.

Lin, T. F., and Wu, J. K. (2001), "Sorption of Arsenite and Arsenate within Activated Alumina Grains: Equilibrium and Kinetics" Wat. Res. Vol. 35, No. 8, pp. 2049-2057

McKay G. (1995), "Use of Adsorbents for the Removal of Pollutants from Wastewaters", $C R C$ Press, $181 \mathrm{pp}$.

Myneni, S. C. B., Traina, S.J., Waychunas, G. A., and Logan, T. J. (1998) "Vibrational Spectroscopy of Functional Group Chemistry and Arsenate Coordination in Ettringite", Geochim. Cosmochim. Acta 62 (19/20), pp. 3285.

Partey, F., Norman, D., Ndur, S., and Nartey, R., (2008), "Arsenic Sorption onto Laterite Iron 
Concretions: Temperature Effect", Journal of colloid and interface Sci., Vol. 321, pp. 493-500.

Singh, B. D., Prasad, G., Rupainwar, D.C. and Singh, V. N, (1988), "As (III) Removal from Aqueous Solution by Sorption", Water, Air, Soil polut., Vol. 42, pp. 373.

Smedley PL, Kinniburgh DG (2002) "A Review of the Source, Behaviour and Distribution of Arsenic in Natural Waters", Applied Geochemistry, pp. 517-568

Vithanage, M., Chandrajith, R., Bandara, A., and Weerasooriya, R. (2006) "Mechanistic Modelling of Arsenic Retention on Red Mud in Simulated Environmental Systems" Journal of Colloid and Interface Science, pp. 265-272.

Williams, M. (2006), "Arsenic in Mine Waters: An International Study", Environmental Geology, Vol. 40, pp. 267-278.

Wills, B. A. (1985), "Maximizing Accuracy of TwoProduct Recovery Computations", Trans. 52 Inst. Min. Metall., Vol. 94, No. 1, pp. 101-102

Yean, S., Cong, L., and Kan, A. (2005), "Sorption/Desorption of Arsenic to Magnetite Nanoparticles", In Abstracts of Papers of the American Chemical Society, Vol. 229, pp. 933

Zhang, S. C., Liu, Z., Luan, X., Peng, H., Ren, J. Wang, J. (2008), "Arsenate Removal from Aqueous Solutions Using Modified Red Mud", Journal of Hazardous Material, pp. 486 - 492.

\section{Authors}

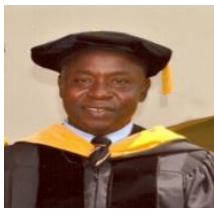

Samuel Agyarko Ndur is a lecturer at the Environmental and Safety Engineering Department of the University of Mines and Technology. He is a $\mathrm{PhD}$ holder from New Mexico Tech. His research interest includes Arsenic sequestration and environmental impacts of mining.

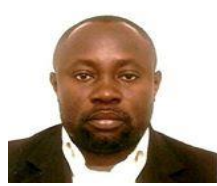

Henry Osei is an entrepreneur. $\mathrm{He}$ is an MSc holder from the University of Mines and Technology, Tarkwa, Ghana. His research interests include Gold Processing and Beneficiation.

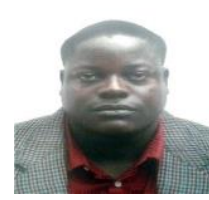

Charles Ebenezer Abbey is a metallurgist at Freeport-McMoRan. He is a PhD holder from Missouri University of Science and Engineering Development, Rolla. His research interest is in the area of Environmental Remediation, Small Scale Process Innovations and Mineral

Processing.

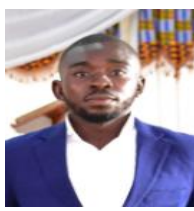

Theophilus Joe-Asare is a Teaching and Research Assistant and $\mathrm{PhD}$ candidate at the University of Mine and Technology (UMaT), Tarkwa, Ghana. He holds a BSc in Environmental and Safety Engineering from (UMaT), Tarkwa, Ghana. He is a member of Ghana Institute of Safety and Environmental Professionals, Red Cross Society and Society of Petroleum Engineers His research interest is in the areas of Fire Risk Assessment, Occupational Hygiene, Accident Investigation and Control and Environmental Sampling and Monitoring. 